\title{
EGU21-3417
}

https://doi.org/10.5194/egusphere-egu21-3417

EGU General Assembly 2021

(c) Author(s) 2022. This work is distributed under

the Creative Commons Attribution 4.0 License.

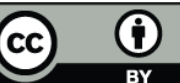

\section{The western termination of the South Pyrenean Triangle Zone; a structural and geophysical characterization.}

\author{
Pablo Santolaria ${ }^{1}$, Concepción Ayala ${ }^{2}$, Emilio L. Pueyo ${ }^{3,4}$, Félix M. Rubio ${ }^{5}$, Ruth Soto ${ }^{3,4}$, Pablo \\ Calvín ${ }^{3}$, Aranzazu Luzón ${ }^{6}$, Adriana Rodríguez-Pintó ${ }^{7}$, Carlota Oliván ${ }^{7}$, and Antonio M. Casas-Sainz ${ }^{6}$ \\ ${ }^{1}$ University of Barcelona, GEOMODELS Research Institute, Spain (pablo.santolaria.otin@gmail.com) \\ ${ }^{2}$ Instituto Geológico y Minero de España, IGME, Tres Cantos, Madrid, Spain. Present address: Geosciences Barcelona, CSIC, \\ Barcelona, Spain \\ ${ }^{3}$ Instituto Geológico y Minero de España, Unidad de Zaragoza, Zaragoza, Spain \\ ${ }^{4}$ Associated Unit in Earth Sciences IGME - Univ. Zaragoza. \\ ${ }^{5}$ Instituto Geológico y Minero de España, IGME, Tres Cantos, Madrid, Spain. \\ ${ }^{6}$ Departamento de Ciencias de la Tierra, Geotransfer Research Group, Instituto de Investigación en Ciencias Ambientales \\ (IUCA), Universidad de Zaragoza \\ ${ }^{7}$ Freelance geologist
}

The presence of multiple evaporite levels strongly influence the structural style and kinematics of fold-and-thrust belts. Particularly (but not exclusively) in their fronts, it is common for these décollements to favor the formation of triangle zones. In the central portion of the Pyrenees, the South Pyrenean Triangle Zone represents the frontal part of this chain, that involves the OligoceneMiocene Ebro Basin foreland deposits. We have focused on its western termination, characterized by a salt-cored anticline that laterally passes to a backthrust which dies out to the west. These structures are detached on the Upper Eocene-Lower Oligocene syntectonic evaporite Barbastro Formation (and lateral equivalents) that acted as a multidetachment unit. To the north, the southdirected Pyrenean thrust unit detached on Middle-Upper Triassic evaporites to finally glide along the Upper Eocene-Lower Oligocene décollement horizons.

In this contribution, we present a detailed structural and stratigraphic model of this triangle zone termination, constructed accordingly to two major approaches (1) constraining the geometry and structural architecture based on surface geology, interpretation of seismic lines $(>900 \mathrm{~km})$ and wells and, (2) obtaining the 3D density distribution of the detachment level (Barbastro Fm. and lateral equivalents as well as deeper, Triassic evaporites) using gravity stochastic inversion by means of more than 7000 gravity stations and 1500 actual density data from surface rocks. All in all, this multidisciplinary approach allows us to characterize the western termination of the South Pyrenean Triangle zone as the transition from a ramp-dominated and multiple triangle zone to a detachment-dominated one whose geometry, kinematics, and location were controlled by the distribution and heterogeneity of the Upper Eocene-Lower Oligocene syntectonic décollements and the southern pinch-out of the basal detachment of this unit. 